\title{
Toasted Full-fat Soya Flour in Treatment of Kwashiorkor
}

\author{
INGRID H. E. RUTISHAUSER AND B. A. WHARTON* \\ From the Medical Research Council Infantile Malnutrition Research Unit, Kampala, Uganda
}

Soya bean formulae have, for some time, received considerable attention as substitutes for human and cows' milk in infant feeding (Dean, 1953), but relatively little is known about the value of soya as a substitute for cows' milk in the treatment of acute kwashiorkor.

Dean (1952) found that the progress of children with uncomplicated kwashiorkor on a locally prepared soya banana mixture was similar to that on the best of the milk protein diets then available, but nevertheless considered that a milk protein diet should be regarded as the treatment of choice for the most severe cases. Thompson (1955), who used the same mixture as Dean, obtained satisfactory results in $55 \%$ of the children treated with soya and in $80 \%$ of those treated with milk in an unselected series of 43 cases with kwashiorkor admitted to Mulago Hospital. The better results with milk were thought to be due partly to the possibility of feeding larger amounts of protein in this form.

More recently, Dutra de Oliveira et al. (1966) have compared a soya formula prepared from an aqueous extract of the bean with a cows' milk formula, containing an equal amount of protein, in the treatment of children with acute malnutrition, and have found that the soya formula was as effective as the cows' milk formula in the initial treatment.

In 1963, Omans, Leuterer, and György investigated a number of soya products in premature infants and showed that a full-fat soya flour produced better gain in weight and less gastro-intestinal disturbance than soya formulae prepared from aqueous extracts of the bean.

In Uganda, as in other countries, hospital treatment of kwashiorkor is, at present, based on the use of dried skimmed milk. The supply of this milk, however, is likely to diminish considerably. In 1966 a toasted full-fat soya flour, which it was hoped to put into local production, became available

\footnotetext{
Received January 26, 1968.

* Present address: Royal Hospital for Sick Children, St. Michael's Hill, Bristol 2.
}

in Uganda and it was decided to investigate the effectiveness of such a flour in the treatment of kwashiorkor. A soya diet for the treatment of acute kwashiorkor would be of particular value in Uganda where lactose intolerance is a frequent occurrence (B. A. Wharton, G. R. Howells, and I. Phillips, 1967, personal communication). The cost of such a diet would also be considerably less than that of the milk protein low-lactose and lactose-free diets at present in use.

\section{Materials and Methods}

A total of $\mathbf{4 2}$ children was studied, all of whom exhibited to a varying degree the clinical signs of kwashiorkor as described by Dean (1960). For the preliminary trial 10 children with mild kwashiorkor were selected and allocated alternately to the milk and soya diets. One of the criteria for inclusion in this trial was that intragastric feeding was unnecessary.

In the main trial 32 children with moderate and severe kwashiorkor were studied. The children were allocated to the milk and soya diets according to a pre-arranged scheme, as a result of which 15 children received the milk and 17 the soya diet. Table I gives the figures for each group on admission for age, percentage expected weight for age, serum protein, serum albumin, and the number of children with a hydroxyproline index greater than 2, which may indicate a bad prognosis (Howells, Wharton, and McCance, 1967). The groups were similar in all respects.

Diets. The milk diets used in these trials were diets that have been in routine use for the treatment of kwashiorkor in the Unit. They were prepared from dried skimmed milk, calcium caseinate (Casilan, Glaxo Laboratories Ltd), cottonseed oil, and sucrose, with added potassium chloride and magnesium hydroxide.

The soya diets were based on two full-fat soya products, one from Wenger Mixer Manufacturing Ltd., and used only in the preliminary trial as it was not suitable for intragastric feeding, and one from the Archer Daniels Midland Company (ADM), which was used in the main trial. The Wenger flour was prepared by the Wenger extrusion-cooking method (Mustakas et al., 1964) and the ADM flour was a steam-heated expeller type product. 
TABLE I

Clinical and Biochemical Data for Children on Admission (mean values and range)

\begin{tabular}{|c|c|c|c|c|c|c|c|c|c|c|}
\hline \multirow{2}{*}{\multicolumn{7}{|c|}{ Diet }} & \multicolumn{2}{|c|}{ Preliminary Trial } & \multicolumn{2}{|c|}{ Main Trial } \\
\hline & & & & & & & Milk & Soya & Milk & Soya \\
\hline $\begin{array}{l}\text { No. of children } \\
\text { Age (mth.) } \\
\text { Percentage of exp } \\
\text { Total serum prote } \\
\text { Serum albumin }\end{array}$ & $\begin{array}{l}\cdots \\
\cdots \\
\text { ed v } \\
\text { (g. } \\
00 \text { r }\end{array}$ & $\begin{array}{l}\ldots \\
\ldots \\
\text { ight for } \\
0 \mathrm{ml} .) \\
\text {... }\end{array}$ & $\begin{array}{c}\cdots \\
\cdots \\
\text { age }\end{array}$ & $\begin{array}{l}\cdots \\
\cdots \\
\end{array}$ & $\begin{array}{l}\cdots \\
\cdots \\
\cdots\end{array}$ & $\begin{array}{l}\cdots \\
\cdots \\
\cdots \\
\cdots\end{array}$ & $\begin{array}{c}5(0) \\
25 \\
(20-32) \\
76 \\
(60-84) \\
4 \cdot 7 \\
(3 \cdot 9-5 \cdot 8) \\
1 \cdot 8 \\
(1 \cdot 5-2 \cdot 1)\end{array}$ & $\begin{array}{c}5(0) \\
24 \\
(14-34) \\
78 \\
(65-92) \\
5 \cdot 6 \\
(4 \cdot 1-7 \cdot 7) \\
1 \cdot 9 \\
(1 \cdot 5-2 \cdot 2)\end{array}$ & $\begin{array}{c}15(5) \\
23 \\
(8-42) \\
72 \\
(48-89) \\
4 \cdot 3 \\
(3 \cdot 5-5 \cdot 7) \\
1 \cdot 4 \\
(1 \cdot 0-2 \cdot 0)\end{array}$ & $\begin{array}{c}17(5) \\
27 \\
(12-50) \\
74 \\
(57-95) \\
4 \cdot 4 \\
(3 \cdot 4-5 \cdot 9) \\
1 \cdot 7 \\
(0 \cdot 9-2 \cdot 3)\end{array}$ \\
\hline
\end{tabular}

* The number of children with a hydroxyproline index greater than 2 is shown in brackets.

Both flours have been described and used by Huang et al. (1965) in infant feeding. Their composition is given in Table II. To the soya flour were added sucrose, cottonseed oil, potassium chloride, and calcium lactate, in proportions such that the final soya formula was similar to the milk formula as regards protein and calories in the preliminary trial, and also potassium and calcium in the main trial.

In the preliminary trial both the milk and soya formulae were fed in conjunction with a mixture of beans, groundnuts, and plantain which provided one-quarter of the protein in the diet. In the main trial the children were allowed plantain or sweet banana in addition to the milk and soya formulae as the appetite improved. All the children received $0.6 \mathrm{ml}$. Abidec (Parke Davis Ltd.) and $5 \mathrm{mg}$. folic acid on alternate days and a single dose of $1000 \mu \mathrm{g}$. $B_{12}$. The diets were given at a level of $4 \mathrm{~g}$. protein per $\mathrm{kg}$. body weight till the second half of the main trial, when the soya formula was limited to $1 \mathrm{~g}$. protein per $\mathrm{kg}$. on the first day and then raised gradually to $4 \mathrm{~g}$. protein per $\mathrm{kg}$. on the fourth day. The composition of the diets, as they were fed per kg. body weight, is given in Table III, together with the mean intake of protein and calories per kg. day, in each group, during the first 14 days of treatment.

Investigations. The children were all studied for the first 14 days of treatment. They were clinically examined and weighed daily, and progress was assessed in terms of the amount of weight lost, the time taken to reach minimum weight, and the rate of weight gain thereafter. Records were kept of the number of days on which the children had to be fed by tube at the beginning, the number of times they vomited, and the number and consistency of the stools.

Total serum protein and serum albumin were measured on admission and on day 14. Total serum protein was measured using a Goldberg refractometer (American Optical Company) and serum albumin by electrophoresis on cellulose acetate by the method of Webster (1965). The hydroxyproline index (Whitehead, 1965) was measured on admission, using the method of Prockop and Udenfriend (1960) as modified by Howells and Whitehead (1967).
In the preliminary trial nitrogen balances were carried out for 4 consecutive 24-hour periods starting on the tenth day of treatment, as previously described by Hadden and Rutishauser (1967). Nitrogen was determined by a micro-Kjeldahl method.

\section{Results}

Preliminary trial (children with mild kwashiorkor). Table IV gives the results of the preliminary trial. In this trial all the children completed 14 days of treatment; the soya diet was

TABLE II

Percentage Composition of Soya Flours

\begin{tabular}{|c|c|c|c|c|}
\hline & & & Wenger & ADM \\
\hline $\begin{array}{l}\text { Protein .. } \\
\text { Fat . } \\
\text { Carbohydrate } \\
\text { Fibre .. } \\
\text { Minerals.. } \\
\text { Moisture }\end{array}$ & $\begin{array}{l}\cdots \\
\cdots \\
\cdots \\
\cdots \\
\cdots\end{array}$ & $\begin{array}{l}\ldots \\
\cdots \\
\cdots \\
\cdots \\
\ldots\end{array}$ & $\begin{array}{r}36 \cdot 0 \\
21 \cdot 6 \\
27 \cdot 1 \\
4 \cdot 2 \\
5 \cdot 2 \\
5 \cdot 9\end{array}$ & $\begin{array}{r}43 \cdot 0 \\
22 \cdot 0 \\
25 \cdot 0 \\
2 \cdot 5 \\
4 \cdot 5 \\
3 \cdot 0\end{array}$ \\
\hline
\end{tabular}

\section{TABLE III}

Composition of the Diets, as Fed per kg. daily, and Mean Intake of Protein and Calories per kg. daily in Each Group

\begin{tabular}{|c|c|c|c|c|c|c|}
\hline \multirow{2}{*}{\multicolumn{2}{|c|}{ Diet }} & & \multicolumn{2}{|c|}{ Preliminary Trial } & \multicolumn{2}{|c|}{ Main Trial } \\
\hline & & & Milk & Soya & Milk & Soya \\
\hline $\begin{array}{l}\text { Protein (g.) .. } \\
\text { Fat (g.) } \quad . \\
\text { Carbohydrate (g.) } \\
\text { Calories (kcal.) } \\
\text { Sodium (mEq) } \\
\text { Potassium (mEq) } \\
\text { Magnesium (mEq) } \\
\text { Calcium (mEq) } \\
\text { Protein intake (g.) } \\
\text { Calorie intake (kcal.) }\end{array}$ & $\begin{array}{l}\cdots \\
\cdots \\
\cdots \\
\cdots \\
\cdots \\
\cdots\end{array}$ & $\begin{array}{l}\cdots \\
\cdots \\
\cdots \\
\cdots \\
\cdots \\
\cdots \\
\cdots \\
\cdots \\
\cdots \\
\cdots\end{array}$ & $\begin{array}{r}4 \cdot 0 \\
3 \cdot 0 \\
20 \cdot 0 \\
121 \cdot 0 \\
5 \cdot 1 \\
8 \cdot 3 \\
3 \cdot 1 \\
5 \cdot 4 \\
3 \cdot 7 \\
112 \cdot 0\end{array}$ & $\begin{array}{r}4 \cdot 0 \\
3 \cdot 4 \\
19 \cdot 4 \\
121 \cdot 0 \\
3 \cdot 8 \\
8 \cdot 5 \\
3 \cdot 9 \\
1 \cdot 2 \\
4 \cdot 1 \\
122 \cdot 0\end{array}$ & $\begin{array}{r}4 \cdot 1 \\
6 \cdot 3 \\
5 \cdot 1 \\
95 \cdot 0 \\
1 \cdot 0 \\
5 \cdot 0 \\
1 \cdot 4 \\
4 \cdot 1 \\
4 \cdot 3 \\
118 \cdot 0\end{array}$ & $\begin{array}{r}4 \cdot 0 \\
5 \cdot 3 \\
6 \cdot 9 \\
91 \cdot 0 \\
0 \cdot 9 \\
5 \cdot 0 \\
1 \cdot 9 \\
4 \cdot 3 \\
4 \cdot 0 \\
103 \cdot 0\end{array}$ \\
\hline
\end{tabular}


TABLE IV

Clinical and Biochemical Findings during 14 Days' Treatment in Children with Mild Kwashiorkor (mean values and range)

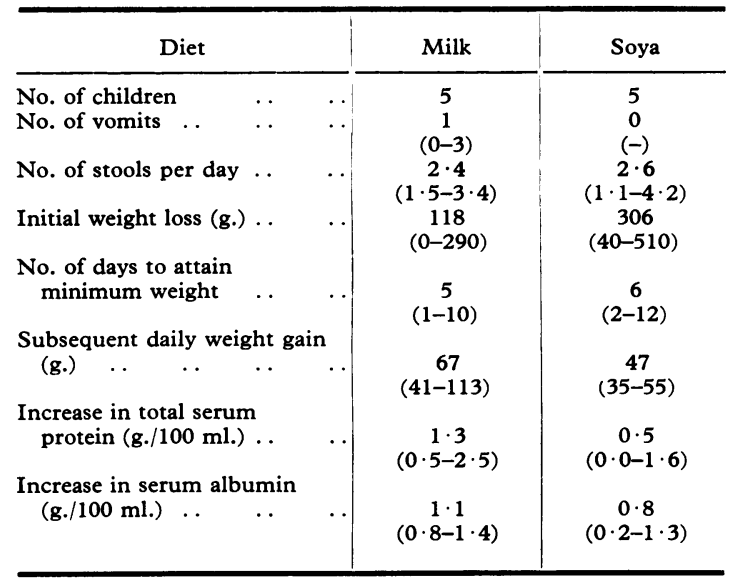

found to be as acceptable as the milk diet, and there were no feeding difficulties or vomiting. All the children made a good clinical response, and there was no difference between the two groups with regard to the number or the consistency of the stools passed, though the soya stools tended to be more bulky.

The children on the soya diet lost more weight initially than those on the milk diet, but the time taken to attain minimum weight was almost the same for both groups. The subsequent gain in weight of the children receiving milk was, however, greater than that of the children receiving the soya, as was the mean rise in total serum protein and serum albumin, but the difference in this case may have been due to the slightly higher values for total

TABLE V

Nitrogen Balance of Children with Mild Kwashiorkor (mean values and range)

\begin{tabular}{|c|c|c|c|c|}
\hline Diet & & & Milk & Soya \\
\hline 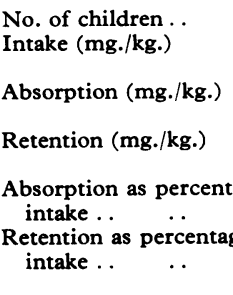 & $\begin{array}{l}\cdots \\
\ldots \\
\ldots \\
\text { age of } \\
\cdots \\
\text { ge of }\end{array}$ & $\begin{array}{c}\cdots \\
\cdots \\
\cdots \\
\cdots\end{array}$ & $\begin{array}{c}5 \\
591 \\
(530-648) \\
466 \\
(418-515) \\
221 \\
(164-292) \\
79 \\
(75-83) \\
\\
37 \\
(31-45)\end{array}$ & $\begin{array}{c}5 \\
614 \\
(522-684) \\
376 \\
(286-493) \\
147 \\
(107-217) \\
61 \\
(46-72) \\
\\
24 \\
(18-32)\end{array}$ \\
\hline
\end{tabular}

serum protein and serum albumin in the soya group on admission.

Table V shows the nitrogen balances which indicate a consistently higher absorption and retention of nitrogen from the milk formula. No correction has been made for faecal metabolic nitrogen.

Main trial (children with moderate and severe kwashiorkor.) In this trial 14 out of the 15 children given milk and 15 out of the 17 given soya completed 14 days treatment on these diets. One child on the milk diet died during the first 14 days and two children on the soya diet were changed to a milk diet because of persistent vomiting.

\section{TABLE VI}

Clinical and Biochemical Findings during 14 Days' Treatment in Children with Moderate and Severe $K$ washiorkor (mean values and range)

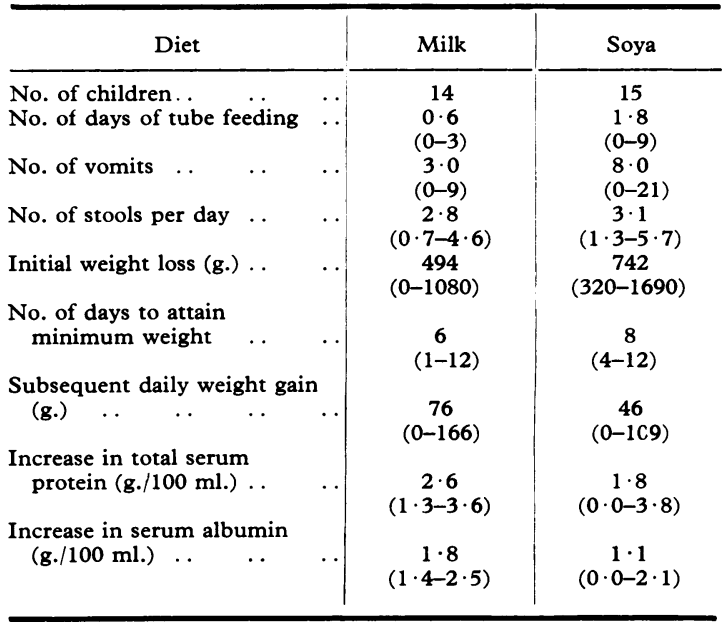

Table VI shows that the children who completed the 14 days treatment responded much better to the milk diet. The soya diet was taken reluctantly by several of the children, and as a result the mean time for which tube feeding was necessary was three times as long in the soya group as in the milk group. Vomiting was also a problem, especially during the first few days of treatment, and it occurred more than twice as often in the soya group as in the milk group. All the children treated with milk responded well, but clinical progress was poor in 4 out of the 15 children treated with soya; 2 of these children still had oedema at the end of 14 days and the skin lesions of the third child showed virtually no improvement; but when these children 
were given milk there was an immediate improvement in all 3. A fourth child was ill throughout the 14 days and died on the 17th day. The total number of stools and the number of loose stools were similar in the two groups. The children on soya lost more weight and took longer to reach their minimum weight than those on milk, and their daily gain in weight subsequently was considerably less, as was the increase in total serum protein and serum albumin.

In an attempt to reduce vomiting during the first few days of treatment, the soya diet was introduced gradually from quarter strength on the first day to full strength on the fourth day after the first 9 patients had had the soya diet. This appeared to be of some value as the average number of vomits per child during the first 5 days was reduced from 6 in 8 children receiving the full strength formula immediately to 2 in 8 children in whom the introduction was gradual.

The general response to treatment and the increase in serum albumin in 2 children who were given a soya formula in which one-quarter of the soya protein had been replaced by calcium caseinate was similar to that with the unmodified soya formula.

\section{Discussion}

Two of the main advantages of a soya diet would be its availability and its relatively low cost compared with a milk diet, particularly a lactose-free diet based on milk. The final cost of any treatment, however, is related to the length of time for which it is required, and from the results of these trials it seems likely that the time required to achieve results with soya would be considerably longer than with milk and, therefore, more costly in children with moderate and severe kwashiorkor.

Although clinically all the children with mild kwashiorkor responded well, even in this group the gain in weight on the soya diet was not as good as on the milk diet. This was probably related to the differences in nitrogen absorption and retention in the 2 groups. In normal infants receiving an intake of nitrogen similar to that of our children, Huang et al. (1967) found that a cows' milk formula was slightly better absorbed (89\%) than the formulae prepared with ADM and Wenger soya flour ( 82 and $83 \%$, respectively), but the retention as a percentage of intake was similar for all three (26-28\% when calculated without taking dermal losses into account). This retention was of the same order as that in our group of malnourished children given Wenger soya flour (24\%), though absorption in this group was only $61 \%$. In our milk group, however, retention was considerably higher (37\%), even though the absorption was a little lower $(79 \%)$ than in the normal infants. Dutra de Oliveira et al. (1966), in Brazil, in a series of malnourished children with oedema, found that the average absorption of nitrogen on soya and milk diets was similar ( 85 and $81 \%$, respectively), but that retention on milk was only $24 \%$ whereas on soya it was $37 \%$ of the intake. They used an aqueous extract of the soya bean and this may be better absorbed by malnourished children than a flour prepared from the whole bean, though Omans et al. (1963) found better nitrogen retention and weight gains in normal infants fed a full-fat soya flour preparation than in those fed a formula prepared from an aqueous extract of the bean.

The children in our study who had moderate or severe kwashiorkor often took the soya reluctantly, and vomiting was a frequent trouble. In the Brazilian study, however, the soya formula was readily accepted and well tolerated, possibly because it was fed at half strength $(1 \cdot 75 \mathrm{~g}$. protein $/ 100 \mathrm{ml}$.) for the first 10 days and at two-thirds strength for the next 6 days, and the full strength formula was only introduced on the 17th day. In our study the amount of vomiting was considerably reduced by the gradual introduction of the soya formula over a period of only 4 days. Extending the introduction of the formula must inevitably increase the length of treatment and, therefore, the cost. We have found that the use of a cows' milk formula enables us to give $4 \mathrm{~g}$. protein per $\mathrm{kg}$. from the first day of treatment, and in this way an average increase of $1.8 \mathrm{~g} . / 100 \mathrm{ml}$. in serum albumin can be achieved in 14 days, whereas in the Brazilian study an increase of only $1.3 \mathrm{~g} . / 100 \mathrm{ml}$. was achieved in 20 days. Similarly, the time taken to attain minimum weight was longer in the Brazilian series, 10 days as compared with 6 days on milk, and 15 days as compared with 8 days on soya in our study. Our results indicate that the rate of weight loss is, in fact, similar on both soya and milk diets, but that because the subsequent rate of gain in weight is greater on milk than on soya, the children on milk appear to lose less weight and to attain minimum weight more rapidly.

The other advantage of a soya diet would be the fact that it is lactose free and should reduce the amount of diarrhoea due to lactose intolerance. In this study only one child who received the soya had lactose intolerance, and she made good progress with very few loose stools.

In conclusion, we must agree with Dean (1952) that a milk protein diet should be regarded as the treatment of choice for children with moderate or severe kwashiorkor, and to add that, though basically 
more expensive, such a diet will prove far less costly in terms of the length of treatment required.

\section{Summary}

Alternative admissions in a series of 10 children with mild kwashiorkor were treated with a diet based on soya; 17 out of 32 children admitted with moderate or severe kwashiorkor were allocated and treated in a similar way. The remainder were given a diet based on milk. Both diets were fed at a level of approximately $4 \mathrm{~g}$. protein and 100 calories per kg. daily.

The children were studied during the first 14 days of treatment. Progress was assessed clinically and in terms of the changes in weight. Total serum protein and serum albumin were measured on admission and on day 14 . Nitrogen balances were carried out in the children with mild kwashiorkor.

In the series with mild kwashiorkor both diets were well accepted and tolerated. All the children made good clinical progress; those receiving soya lost more weight initially and their subsequent rate of gain was less than in those receiving milk; the increase in total serum protein and serum albumin was slightly greater, and nitrogen absorption and retention consistently higher, in the children receiving milk.

In the series with moderate and severe kwashiorkor there were greater differences. The soya diet was taken reluctantly by a number of the children, and in them tube-feeding was necessary for a longer period than in the children receiving milk. Vomiting was more troublesome in the children receiving soya, but it was possible to reduce this by introducing the diet more gradually. Clinical progress in all the children treated with milk was good, but in 4 of the children treated with soya it was poor. In 3 of these there was an immediate improvement when milk was given. The children receiving soya lost more weight initially and the subsequent rate of gain was considerably less than in those receiving milk. The increase in total serum protein and serum albumin was greater in the children receiving milk.

A diet based on milk should be the treatment of choice for children with moderate and severe kwashiorkor; though basically more expensive, such diets will prove less costly in terms of length of treatment.

The authors wish to thank the nursing and laboratory staff of the Infantile Malnutrition Research Unit for their co-operation and assistance, and Professor R. A. McCance for his support and advice.

\section{REFERENCES}

Dean, R. F. A. (1952). The treatment of kwashiorkor with milk and vegetable proteins. Brit. med. f., 2, 791.

(1953). Plant proteins in child feeding. Spec. Rep. Ser. med. Res. Coun. (Lond.), 279, 26.

- (1960). Treatment of kwashiorkor with moderate amounts of protein. f. Pediat., 56, 675.

Dutra de Oliveira, J. E., Scatena, L., de Oliveira Netto, N., and Duarte, G. G. (1966). The nutritive value of soya milk and cows' milk in malnourished children. A comparative study. ibid., 69, 670 .

Hadden, D. R., and Rutishauser, I. H. E. (1967). Effect of human growth hormone in kwashiorkor and marasmus. Arch. Dis. Childh., 42, 29.

Howells, G. R., Wharton, B. A., and McCance, R. A. (1967). Value of hydroxyproline indices in malnutrition. Lancet, $\mathbf{1}$, 1082.

—, and Whitehead, R. G. (1967). A system for the estimation of the urinary hydroxyproline index. F. med. Lab. Technol., 24, 98.

Huang, P. C., Tung, T. C., Lue, H. C., Lee, C. Y., and Wei, H. (1967). Feeding of infants with full-fat soya bean-rice foods. F. trop. Pediat., 13, 27.

-, , and Wei, H. (1965). Feeding of infants with toasted full fat soybean foods. [Jap.] F. Formosan med. Ass., 64, 591.

Mustakas, G. C., Griffin, E. L., Allen, L. E., and Smith, O. B. (1964). Production and nutritional evaluation of extrusion cooked full-fat soy bean flour. F. Amer. Oil Chem. Soc., 41, 607.

Omans, W. B., Leuterer, W., and György, P. (1963). Feeding value of soy milks for premature infants. F. Pediat., 62, 98.

Prockop, D. J., and Udenfriend, S. (1960). A specific method for the analysis of hydroxyproline in tissue and urine. Analyt. Biochem., 1, 228.

Thompson, M. D. (1955). Comparison of milk and soya beans in the treatment of kwashiorkor in Uganda. Brit. med. $\mathcal{F}$., 2, 1366.

Webster, D. (1965). A simple method of serum protein fractionation on cellulose acetate and comparison of the albumin levels with a method of sodium sulphite fractionation. Clin. chim. Acta, 11, 101.

Whitehead, R. G. (1965). Hydroxyproline creatinine ratio as an index of nutritional status and rate of growth. Lancet, 2, 567. 